\title{
Pancreaskreft kan påvises tidlig med en urinprøve
}

\author{
Cancer pancreas kan oppdages i tidlig fase ved å måle tre proteiner \\ i urin.
}

Pancreaskreft har oftest en dårlig prognose, fordi diagnosen vanligvis stilles altfor sent. I en fersk studie publisert i tidsskriftet Clinical Cancer Research beskrives tidlig diagnostikk av pancreaskreft basert på målinger av tre proteiner, REG1A, TFF1 og

LYVE1, i urin (1). Med denne urinprøven kan duktale adenokarsinomer i pancreas i stadium I-II oppdages med en presisjon på over $90 \%$. Dersom urinprøven kombineres med serummåling av CA19-9-protein, øker den diagnostiske presisjonen ytterligere. Testen

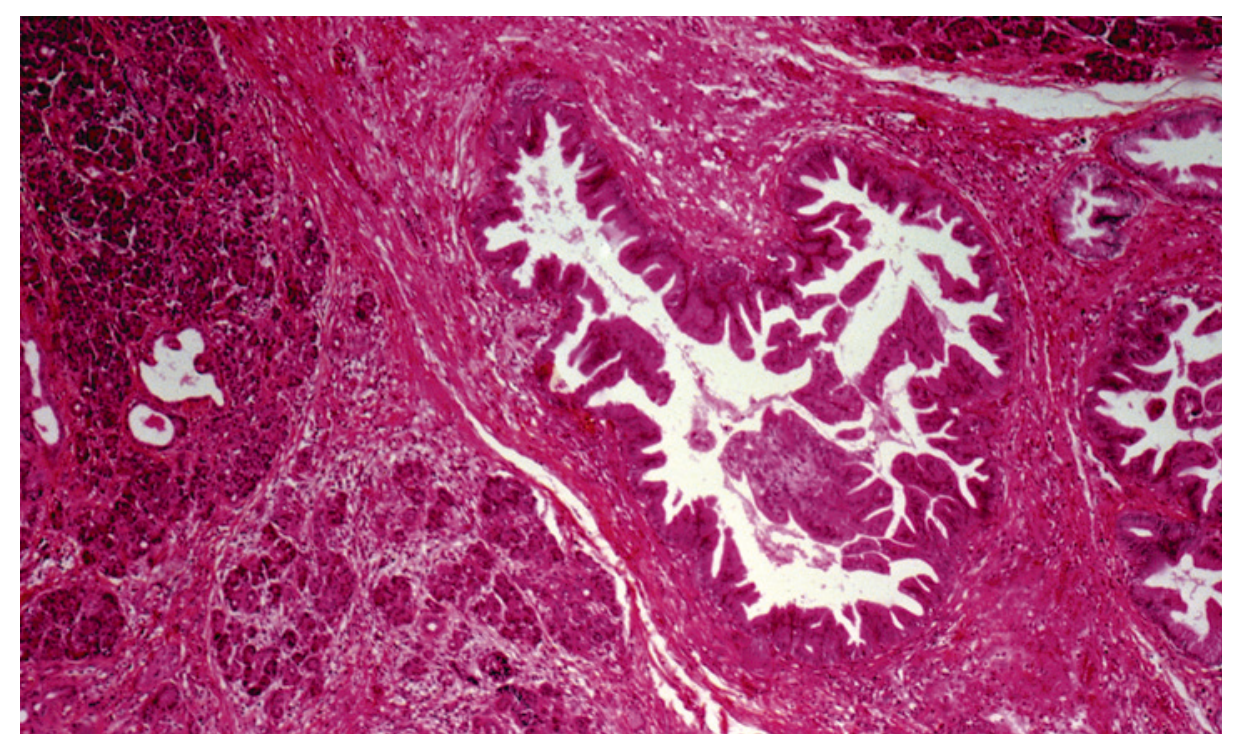

Illustrasjonsfoto: Science Photo Library

\section{Myoklonus etter hjertestans}

\section{Myoklonus bør ikke brukes som et prognostisk dårlig tegn etter hjertestans, viser ny studie.}

Myoklonus er korte, ufrivillige rykninger i muskulatur og er et vanlig tegn på nevrologisk skade etter hjertestans. Myoklonus, spesielt vedvarende myoklonus, etter gjenoppliving ved hjertestans har i tidligere studier vært assosiert med dårlig prognose.

I en nylig publisert studie ble over 2500 voksne overlevende etter hjertestans i Europa og USA inkludert, hvorav $88 \%$ var behandlet med hypotermi (1). 471 (18\%) utviklet myoklonus. I denne gruppen hadde det sjeldnere vært bevitnet stans, den totale iskemitiden var lenger og det hadde gått lengre tid til hjerte-lunge-redning utført av helsepersonell. Disse pasientene hadde sjeldnere ventrikulær takykardi eller ventrikkelflimmer som initial hjerterytme. EEG viste myoklonus med epileptogen aktivitet hos over halvparten. Av dem med myoklonus hadde $9 \%$ et godt utfall. De fleste av disse hadde ingen epileptogen aktivitet ved EEG.

- Behandlingsrutinene etter gjenoppliving ved hjertestans har utviklet seg mye de siste årene, og resultatene er blitt vesentlig bedre, sier Michael Busch, som er overlege og ph.d. ved anestesiavdelingen ved Stavanger universitetssjukehus. Dermed kan man stille spørsmål ved den prediktive verdien av klassiske cerebrale prognoseparametere. Denne kan dermed gi tilgang til kurativ behandling for en rekke pasienter og være en billig og god screening for høyrisikogrupper, skriver forfatterne.

- Disse resultatene er oppsiktsvekkende, både fordi den rapporterte diagnostiske treffsikkerheten er høy og fordi andre biomarkører for denne kreftformen nesten ikke finnes, sier Trond Buanes, professor ved Oslo universitetssykehus. Videre utprøvning av denne testen bør gjøres i pasientgrupper med kjent risiko for pancreaskreft, slik som storrøykere, pasienter med kronisk pankreatitt eller nyoppdaget diabetes. Screening av friske personer vil trolig gi mange falskt positive resultater. Den nye diagnostikken må følges opp med bildediagnostikk med høy kvalitet, kombinert med mulighet for endoskopisk ultralydundersøkelse med finnålsaspirasjon av små pancreaslesjoner med usikkert radiologisk utseende.

- Den nye undersøkelsesmetoden er en ny og svært lovende mulighet til å påvise kreft i bukspyttkjertelen i tidlig fase. Testen bør tas i bruk snarest mulig, mener Buanes.

\section{Inge Rasmus Groote}

Tidsskriftet

\section{Litteratur}

1. Radon TP, Massat NJ, Richard Jones R et al. Identification of a Three-Biomarker Panel in Urine for Early Detection of Pancreatic Adenocarcinoma. Clin Cancer Res 2015; 21: 3512-21. studien viser at myoklonus etter hjertestans ikke kan anvendes som et prognostisk dårlig tegn alene og at videre behandling i slike situasjoner ikke er meningsløs. Ved tvil bør observasjonstiden forlenges. Adekvat behandling av disse pasientene er kompleks og bør foregå på sykehus med intensivmedisinsk, kardiologisk, nevrologisk og nevrofysiologisk kompetanse, sier han.

\section{Liv-Ellen Vangsnes \\ Tidsskriftet}

\section{Litteratur}

1. Seder DB, Sunde K, Rubertsson $S$ et al. Neurologic outcomes and postresuscitation care of patients with myoclonus following cardiac arrest. Crit Care Med 2015; 43: 965-72. 